\title{
Promosi Kesehatan Melalui Media Film Dalam Upaya Meningkatkan Perilaku Hidup Bersih dan Sehat Anak Sekolah Dasar Wilayah Pesisir Kepulauan
}

\author{
Selviana \\ Universitas Muhammadiyah Pontianak \\ selviana@unmuhpnk.ac.id \\ Linda Suwarni \\ Universitas Muhammadiyah Pontianak \\ linda.suwarni@unmuhpnk.ac.id
}

\begin{abstract}
Abstrak
Masih rendahnya sanitasi lingkungan dan Perilaku Hidup Bersih dan Sehat di wilayah pesisir kepulauan menyebabkan potensi terjadinya beberapa penyakit, seperti diare, kolera, dan soil transmitted helminthes (STH). Kegiatan pengabdian masyarakat ini bertujuan untuk meningkatkan pengetahuan, sikap, dan perilaku PHBS dalam upaya menurunkan kejadian penyakit berbasis lingkungan melalui inovasi teknologi media promosi kesehatan yang menarik. Metode partisipatif digunakan untuk melibatkan masyarakat secara aktif dalam pelaksanaan penerapan teknologi Inovasi Teknologi Promosi Kesehatan PHBS. Inovasi teknologi promosi kesehatan, berupa media film PHBS melalui penyediaan sarana tempat cuci tangan percontohan. Kegiatan ini akan dilakukan untuk, oleh, dan dari masyarakat sebagai mitra dalam kegiatan pengabdian ini melalui musyawarah masyarakat desa untuk menganalisis permasalahan di wilayah mereka, urgensi dan prioritas masalah bersama, serta menentukan solusi dari masalah yang ada, khususnya terkait dengan kejadian penyakit berbasis lingkungan yang ada di wilayah mereka. Peningkatan pengetahuan dan sikap anak SD yang diperoleh dari pre-test dan post-test dianalisis dengan uji t berpasangan dengan taraf kepercayaan $95 \%$. Hasil pre dan post menunjukkan adanya perbedaan pengetahuan (yang awalnya 8,78 menjadi 10,90) dan sikap (yang awalnya 7,38 menjadi 9,52) yang signifikan $(p<0,05)$. Dengan demikian, edukasi melalui media Film dapat meningkatkan pengetahuan dan sikap anak SD tentang hidup sehat.
\end{abstract}

Kata Kunci : Promosi Kesehatan, PHBS, CTPS. Film 


\section{Jurnal Abdimas Mahakam}

https://journal.uwgm.ac.id/index.php/abdimasmahakam

\section{Online ISSN : 2549-5755 \\ Juni 2018, Vol.2 No. 2}

\section{PENDAHULUAN}

Indeks Pembangunan Manusia (IPM) Kalimantan Barat menduduki rangking ke 29 dari 34 propinsi di Indonesia. Khusus di bidang kesehatan, IPM dibagi lagi menjadi Indeks Pembangunan Kesehatan Masyarakat (IPKM) yang merupakan indeks komposif dari 30 indikator kesehatan. IPKM di Kalimantan Barat nilainya meningkat, akan tetapi dari rangking di Indonesia tidak jauh berbeda (Dinkesprop Kalbar, 2017). Salah satu permasalahan yang masih banyak terjadi di kabupaten/Kota di Kalimantan Barat adalah penyakit berbasis lingkungan, khsususnya banyak terjadi di daerah pesisir dan sungai.

Salah satu penyakit berbasis lingkungan di daerah pesisir dan sungai yang banyak menyerang anak-anak adalah diare dan kecacingan, termasuk di Desa Sungai Raya Kecamatan Sungai Raya Kepulauan (Profil Puskesmas Sungai Raya Kepulauan, 2016). Hal ini dapat mengganggu pertumbuhan dan perkembangan anak. Salah satu faktor yang berhubungan signifkan adalah pengetahuan dan perilaku hidup bersih dan sehat (Suwarni, Fahri, dan Selviana, 2016).

Selama ini promosi kesehatan sangat minim dilakukan. Promosi kesehatan yang dilakukan hanya sebatas penyuluhan dan pembagian poster, hal ini pun sangat jarang dilakukan. Sehingga hal tersebut dirasa kurang memberikan manfaat yang besar. karena penyuluhan kesehatan selama ini hanya dilakukan di posyandu. Selain itu, metode penyuluhan juga terkesan kurang menarik, banyak masyarakat yang kurang mendengar informasi yang disampaikan oleh penyuluh, sehingga akan dillakukan inovasi teknologi promosi kesehatan melalui media film dan media Cuci Tangan Pakai Sabun (CTPS) yang akan dilakukan di SD di Sungai Raya Kecamatan Sungai Raya Kepulauan.

Beberapa penelitian terdahulu menunjukkan bahwa media Film efektif dalam meningkatkan pengetahuan dan perilaku pada anak sekolah dasar (Siwi, Yunitasari, dan Krisnana, 2014; Tandilangi, Mintjelungan, dan Wowor, 2016). Tujuan dari pengabdian ini adalah untuk meningkatkan pengetahuan, sikap, dan perilaku PHBS dalam upaya menurunkan kejadian penyakit berbasis lingkungan melalui inovasi teknologi media promosi kesehatan yang menarik, yaitu melalui media Film.

\section{METODE}

Metode partisipatif dan pendampingan digunakan untuk melibatkan masyarakat secara aktif dalam pelaksanaan penerapan teknologi Inovasi Teknologi Promosi Kesehatan PHBS. Inovasi teknologi promosi kesehatan, berupa media film PHBS dan penyediaan sarana tempat cuci tangan percontohan. Kegiatan ini dilakukan untuk, oleh, dan dari masyarakat sebagai mitra dalam kegiatan pengabdian ini melalui musyawarah masyarakat desa untuk menganalisis permasalahan di wilayah mereka, urgensi dan prioritas masalah bersama, serta menentukan solusi dari masalah yang 


\section{Jurnal Abdimas Mahakam}

https://journal.uwgm.ac.id/index.php/abdimasmahakam

\section{Online ISSN : 2549-5755 \\ Juni 2018, Vol.2 No. 2}

ada, khususnya terkait dengan kejadian penyakit berbasis lingkungan yang ada di wilayah mereka.

Untuk mengetahui efektifitas terhadap introduksi teknologi promosi kesehatan PHBS melalui pemberian pre test dan Post test pada anak sekolah dasar di Desa Sungai Raya Kecamatan Sungai Raya Kepulauan Kabupaten Bengkayang. Media yang digunakan dalam pengabdian ini sudah dilakukan evaluasi oleh ahli media, ahli materi, dan kelompok kecil masyarakat umum memberikan hasil yang baik. Kegiatan pengabdian ini dilaksanakan selama 2 bulan.

\section{HASIL DAN PEMBAHASAN}

Kegiatan pengabdian ini dimulai dengan persiapan film yang dipilih sesuai dengan karakteristik sasaran. Sasaran dalam kegiatan ini adalah anak SD. Film PHBS yang dibuat menampilkan karakter kehidupan sehari-hari anak-anak di Desa tersebut. Film ini menceritakan tentang perilaku anak yang makan tidak mencuci tangan terlebih dahulu, membuang sampah sembarangan dan masih ada yang buang air besar sembarangan. Film ini juga dijelaskan langkah-langkah cuci tangan yang baik dan benar, sehingga diharapkan terjadinya edukasi pada anak-anak mengenai PHBS melalui media yang menarik bagi anak-anak.

Pelaksanaan kegiatan ini dilakukan sebanyak 2 tahap, yaitu promosi kesehatan melalui pemutaran film dan praktek cuci tangan pakai sabun.

Didahului oleh pembagian pre test yang bertujuan untuk mengetahui tingkap pemahaman/ pengetahuan awal dari siswa siswi SD Negeri 11 mengenai PHBS sebelum dilakukan kegiatan. Setelah pre test dilakukan, selanjutnya dilakukan pemutaran film mengenai PHBS yang berdurasi 20 menit. Setelah itu diberi penjelasan dan tanya jawab mengenai film tersebut. Setelah tanya jawab dilakukan, selanjutnya adalah pelatihan gerakan cuci tangan pakai sabun yang baik dan benar. Siswa siswi diajarkan langkah-langkah cuci tangan pakai sabun tersbeut dengan sebuah lagu. Sehingga mereka dengan cepat memahami langkah-langkah CTPS .

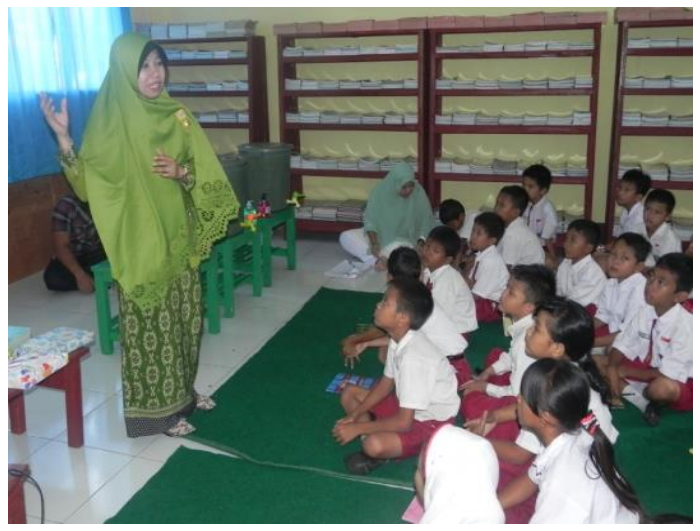

Gambar 1.Pemutaran Film PHBS 


\section{Jurnal Abdimas Mahakam}

https://journal.uwgm.ac.id/index.php/abdimasmahakam

\section{Online ISSN : 2549-5755 \\ Juni 2018, Vol.2 No. 2}

Setelah kegiatan berlangsung selama 2,5 jam barulah dilakukan kembali pembagian post test untuk mengukur perbedaan tingkat pengetahuan siswa siswi sebelum dan sesudah promosi kegiatan mengenai PHBS dilaksanakan. Berikut ini hasil pretest dan posttest yang dilakukan:

\begin{tabular}{|c|c|c|c|c|}
\hline \multicolumn{2}{|c|}{ Variabel } & Mean & Standar deviasi & $p$ value \\
\hline \multirow[t]{2}{*}{ Pengetahuan } & Sebelum & 8,78 & 1,972 & \multirow{2}{*}{0,000} \\
\hline & Sesudah & 10,90 & 0,763 & \\
\hline \multirow[t]{2}{*}{ Sikap } & Sebelum & 7,38 & 1,713 & \multirow{2}{*}{0,000} \\
\hline & Sesudah & 9,52 & 0,707 & \\
\hline
\end{tabular}

Tabel di atas menunjukkan bahwa terdapat peningkatan skor mean pengetahuan sebelum dan sesudah pendidikan kesehatan dengan media komik dan film pendek, yaitu sebesar 2,12. Peningkatan skor pengetahuan tersebut signifikan ( $p$ value < 0,05). Selain pengetahuan, tabel di atas juga menunjukkan jadanya peningkatan skor sikap sebelum dan sesudah dilakukan pendidikan kesehatan dengan media komik dan film pendek, yaitu sebesar 2,14 yang signifikan ( $p$ value < 0,05). Hal ini menunjukkan bahwa promosi kesehatan dengan media film pendek efektif terhadap peningkatan pengetahuan dan sikap siswa SD tentang PHBS.

Kegiatan pengabdian ini bertujuan untuk memberikan promosi kesehatan untuk siswa siswi di sekolah mengenai Perilaku Hidup Bersih dan Sehat (PHBS) dan Cuci Tangan Pakai Sabun (CTPS). Promosi kesehatan dilakukan melalui media film yang bertujuan agar menarik minat siswa siswi untuk menyimak informasi kesehatan yang terkandung dalam film tersebut. Siswa siswi sebagai agent of change perilaku kesehatan di lingkungan keluarga.

Perubahan pengetahuan dan sikap tentang 22 ni akan berdampak pada perilaku dalam menerapkan PHBS tersebut. Menurut suwarni, dkk (2016) menyatakan bahwa pengetahuan, sikap dan perilaku PHBS mampu mencegah penyakit berbasis lingkungan, seperti diare,kecacingan, dan lain-lain.

Pendidikan kesehatan dengan media audio visual telah memberikan perubahan positif terhadap pengetahuan dan sikap siswa. Hal ini dikarenakan media audio visual (film pendek) lebih menarik karena memadukan audio dan visual, sehingga pesan yang ada lebih mudah tersampaikan dan dipahami oleh anak. Menurut Piaget, anak usia SD mulai berpikir nyata, sehingga penyampaikan pendidikan kesehatan melalui film lebih mudah diserap oleh mereka (Santrock, 2012). Kemampuan video dalam memvisualisasikan materi terutama efektif untuk membantu anda menyampaikan materi bersifat dinamis. Materi memerlukan visualisasi mendemonstrasikan hal-hal seperti gerakan motorik tertentu, ekspresi wajah, maupun suasana lingkungan tertentu adalah paling baik disajikan melalui teknologi video (Arsyad, 2011).

Perilaku hidup bersih dan sehat merupakan sekumpulan perilaku yang dilakukan atas dasar kesadaran sebagai hasil dari pembelajaran yang sudah mereka dapatkan dapat 


\section{Jurnal Abdimas Mahakam}

https://journal.uwgm.ac.id/index.php/abdimasmahakam

\section{Online ISSN : 2549-5755 \\ Juni 2018, Vol.2 No. 2}

menolong diri sendiri di bidang kesehatan dan berperan aktif dalam mewujudkan kesehatan masyarakat. Beberapa penelitian menunjukkan media film efektif dalam meningkatkan pengetahuan dan sikap serta perilaku hidup bersih dan sehat pada anak (Sari, 2010; Eriyanto dan Maridana, 2012; Nurfitriani, 2017). Sejalan dengan penelitian ini, anak SD yang mendapatkan pendidikan kesehatan melalui media film pendek efektif dalam meningkatkan pengetahuan, sikap, dan perilaku hidup bersih dan sehat mereka sehari-hari. Dengan demikian, diharapkan melalui PHBS yang diterapkan anak-anak SD di sekolah dapat mengurangi kejadian penyakit berbasis lingkungan yang banyak terjadi di daerah pesisir, khususnya Desa Sungai Raya, seperti kecacingan dan diare.

Pemberian informasi tentang perilaku hidup bersih dan sehat media film pendek merupakan proses belajar untuk mengembangkan pengertian yang benar dan perilaku positif terhadap kesehatan. Setelah dilakukan pendidikan kesehatan ini siswa dapat menerapkan perilaku hidup bersih dan sehat secara benar.

Praktek cuci tangan pakai sabun (CTPS) juga dilaksanakan setelah kegiatan edukasi di kelas selesai dilaksanakan. Kegiatan Praktek CTPS ini didahului dengan penyerahan media CTPS berupa ember yang terdapat keran ,sabun cair dan serbet. Alat-alat tersebut diberikan guna menunjang perilaku CTPS di sekolah.Pemberian stimulasi ini dapat meningkatkan keterampilan dari kelompok sasaran (Fitriana dan Arbain, 2017; Suwarni, dkk., 2018).

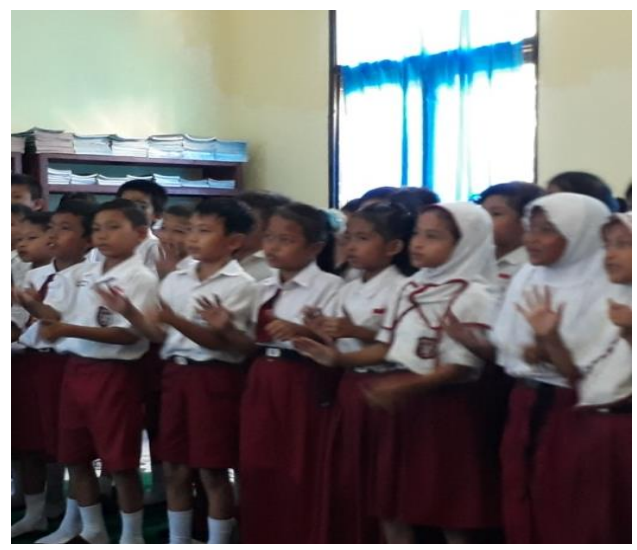

Gambar 2.

Simulasi Praktek Cuci Tangan Pakai Sabun 


\section{Jurnal Abdimas Mahakam}

https://journal.uwgm.ac.id/index.php/abdimasmahakam

\section{Online ISSN : 2549-5755 \\ Juni 2018, Vol.2 No. 2}

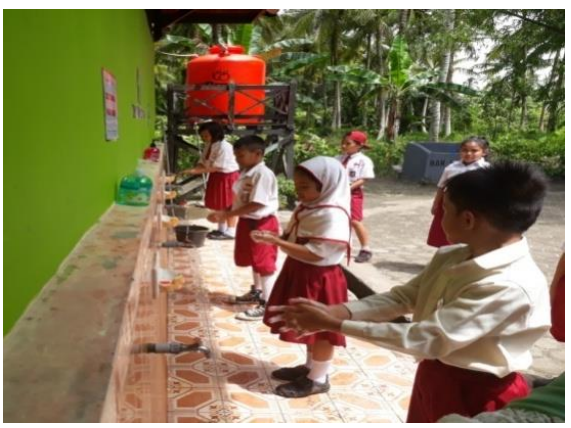

Gambar 3.

Praktek Cuci Tangan Pakai Sabun oleh Siswa SD Sungai Raya Kepulauan

Setelah pemberian media CTPS diberikan, maka selanjutnya adalah praktek CTPS oleh siswa siswi. Yang mana langkah-langkah CTPS telah diajarkan pada sesi promosi kesehatan sebelumnya. Kegiatan praktek CTPS ini dilakukan untuk memastikan pemahaman siswa siswi terhadap CTPS sebagai upaya prefentif dalam mencegah penyakit-penyakit berbasis lingkungan, seperti diare, kecacingan, dan lainlain. Dari praktek tersebut terlihat siswa siswi telah memahami langkah-langkah CTPS, sehingga siswa siswi yang telah mengikuti kegiatan ini diharapkan dapat menjadi model dalam menerapkan PHBS di sekolah maupun dirumah, khususnya mengenai CTPS.

\section{PENUTUP}

Pemberian edukasi melalui media film pendek efektif dalam meningkatkan pengetahuan dan sikap anak sekolah dasar dalam perilaku hidup bersih dan sehat, terutama berkaitan dengan cuci tangan pakai sabun. Edukasi yang komprehensif, tidak hanya kepada anak sekolah dasar, tetapi juga kepada keluarga, sekolah dan masyarakat, menggunakan media yang mudah dipahami dan menarik, sebagaimana dilakukan pada program pengabdian masyarakat ini.

Media edukasi berupa film pendek yang digunakan telah lolos uji coba dengan baik sebelum dipakai. Evaluasi terhadap media yang dilakukan oleh ahli media, ahli materi, dan kelompok kecil masyarakat umum memberikan hasil yang baik. Kegiatan edukasi semacam ini perlu dilakukan terus-menerus, dalam skala yang lebih luas,supaya bisa menjangkau masyarakat secara luas. 


\section{Jurnal Abdimas Mahakam}

https://journal.uwgm.ac.id/index.php/abdimasmahakam

\section{Online ISSN : 2549-5755}

Juni 2018, Vol.2 No. 2

\section{DAFTAR PUSTAKA}

Andaruni,A., Fatimah, S., Sumangunsang,B. Gambaran Faktor -Faktor Penyebab Infeksi Cacingan pada Anak di SDN 01 Pasirlangu Cisarua. Fakultas Ilmu Keperaatan Unpad.

Fitriana, R., Nur, D. R., \& Arbain, A. (2017). Pelatihan dan Simulasi IELTS bagi Mahasiswa dan Dosen di Lingkungan Fakultas Pendidikan dan Keguruan Program Studi Bahasa Inggris Universitas Widya Gama Mahakam Samarinda. Jurnal Abdimas Mahakam, 1(2), 88-95.

Hayati, Mawar. 2009. Pengaruh Peer Education Pentingnya Gizi Terhadap Perilaku Anak Usia Sekolah Dalam Menentukan Jajanan Sehat Di Kota Lhokseumawe. Program Pascasarjana. Universitas Indonesia Depok.

Nurfitriani, 2017. Efektifitas Film Dan Leaflet Terhadap Perilaku Hidup Bersih Sehat Pada Siswa Kelas Iii Di Sekolah Dasar Sungapan 03 Kota Pemalang. Repository. Bachelor of Public Health. Faculty of Health Science. DINUS University. 2017

Puskesmas Sungai Raya Kepulauan. 2016. Profil Puskesms Sungai Raya Kepualauan. Puskesmas Sungai Raya Kepulauan : Bengkayang.

Sari, D. A. (2010). Pengaruh promosi kesehatan tentang PHBS.

Santrock, John W. 2012. Life-span Development. 13 th Edition. University of Texas, Dallas : Mc Graw-Hill

Suwarni, L., Selviana., Fachri,M., 2016. Determinan of Environmental Disease In Health Promotion of Community Lead Total Sanitation (CLTS) on Elementary Students as Primary Prevention in Isolated District, Indonesia. SMU Medical Journal. Vol 3 No1.

Suwarni, L., Selviana., Sarwono, E., Ruhama, U. (2018). Pemberdayaan Masyarakat Melalui PENKES (Pendidikan dan Kesehatan) untuk Meningkatkan Derajat Kesehatan Masyarakat. Jurnal Abdimas Mahakam, 2(1), 16-23.

Tandilangi, M., Mintjelungan,C., Wowor,V., 2016. Efektivitas dental health education dengan media animasi kartun terhadap perubahan perilaku kesehatan gigi dan mulut siswa SD Advent 02 Sario Manado. Jurnal e-Gigi (eG), 4 (2), Juli-Desember 2016

Yuliwulandari, R., Zahroh, H., Susilowati., Hendri,F., Usman. Media Edukasi Berbasis Cetak dan Digital tentang Pengobatan Lepra dan Efek Samping Obat Mempermudah pemahaman penderita Lepra, Keluarga, Masyarakat, dan Tenaga Kesehatan di Tanjung Pasir tentang Lepra dan Terapinya. Jurnal Pengabdian kepada Masyarakat, 3(1), September 2017. 